\title{
画像処理によるギルスライバの混合むらの解析
}

（第 1 報）混合むらの定量化

\author{
野田 隆弘*，近田冨士雄**，岡村 政明**
}

\section{Analysis of Blend irregularity in Gill Sliver by Image Processing \\ Part 1: Quantification of Blend Irregularity}

\author{
Takahiro Noda, Fujio Konda and Masaaki Okamura \\ Faculty of Engineering, Gifu University, 1-1 Yanagido, Gifu
}

\begin{abstract}
A general-purpose image processing analyzer was used to evaluate the blend irregularity in sliver by mean and standard deviation of detected blend ratio, which was obtained from the brightness of the image. The image of the black and white blended sliver was taken with a CCD camera.

The influence of number of gilling, fiber length, blending system and feeding direction on the blend irregularity was discussed. In sliver blending, as the number of gilling is increased, the blend irregularity is remarkably reduced. In stock blending process, the blend irregularity is small and it shows nearly the same value irrespective of number of gilling. This fact indicates that the sufficiently blend has been obtained in the stock blending process. In sliver blending process, the sliver composed of fibers with the same length shows better blending than that of different length fibers. In reverse direction feeding, the blend irregularity of sliver is better than that of the forward direction feeding.
\end{abstract}

(Received July 28, 1997)

(Accepted for Publication May 8, 1998)

\section{1. 緒 言}

繊維製品に対する需要の高度化，個性化，多様化 および繊維製品の輸入の急増により差別化商品, 高 付加価值技術の開発が求められている. 紡績工程に おいて,これまでのところ, 特性の類似した各種緎 維により混紡が行われてきた. しかし，最近ではこ のようなニーズに対応するために，物性の極端に異 なる緘維による混紡が行われるようになり，高度な 混紡技術の開発, 混合状態の解析に関する研究が要 求されている，最終工程において，良好な混合状態 を得るためには練条工程において十分に混合されて いることである. したがって，この段階における混 合状態の評価, 解析を行うことは重要であると考え
られる.

従来から，スライバの混合むらにおける良否の判 断は, 紡績工程における主要な管理項目の 1 つとし て，豊富な経験をもち，高度に熟練した作業者の目 視による，官能検查が行われている。しかし，この 方法は定性的であり，同一個人および作業者間の感 覚にばらつきが存在している，また，その評価技術 を習得するまでにかなりの訓練期間を要するなどい くつあの問題点があり, 定量的な評価方法の確立を 図ることが求められている.

これまでのところ, 混合むらの測定, 評価に関す る研究は混紡系の断面を顕微鏡で検鏡し, 混合率の 分布を求めるなど糸を対象としたものが多く行われ てきている. ${ }^{1 \sim 5)}$ しかし，スライバは糸と比較して瀻

*会員, Member, 岐阜市立女子短期大学, Gifu City Women's College, 岐阜市長良, Nagara Gifu, * * 会員, Member, 岐阜大学 工学部, Gifu University, 岐阜市柳戸, Yanagido Gifu 
維の構成本数が非常に多く, 系の場合と同様な手法 では混合むらの測定が困難である. 近年, 光技術, 画像処理技術およびコンピュータによるデー夕処理 技術の著しい進歩・発展がみられ，これらの機能を 搭載した汎用機器が広く一般に使用されてきてい る.したがって，これまで測定が困難であったスラ イバのような太い織維束の分野においても，これら の試験機器を用いて, 混合むらを測定および評価す ることができれば, いち早く結果を生産現場へフィ 一ドバックさせ, 製品の品質向上に大いに寄与する ことが期待される. しかも, これらの評価方法は定 量的であり, 評価者間の差, 評価者個人のばらつき などの課題をほとんど解消することができ, 加えて 高度な技能を必要とせず，初心者であ常に安定した 測定を行うことが可能である.

近田ら ${ }^{6 \sim 8)}$ は光電子増倍管を用いて加工条件が混 合むらに及ぼす影響を求め, スライバの構造を解析 している. 岡村ら ${ }^{9.10)}$ はラインセンサを用いて, 加工 条件がスライバの混合欠陥に及ぼす影響を考察して いる，前者においては，紡出中のスライバの長さ方 向に沿ってスライバの中央部分の混合むらを測定, 解析しており, また, 後者はスライバの幅方向にお ける混合むらを断続的に测定している. しかし, こ れらはいずれあスライバ表面全体の様相については 追究されていない.

本報では近年，広く一般に使用されるようになっ た画像処理装置により, 混合スライバの表面全体の 混合むらを評価することを目的とした．ギルを通す 回数, スライバの構成繊維長, スライバの供給方向 および繊維の混合方式の加工条件がスライバの混合 むらに及ぼす影響を求めた。 得られた結果は視覚に よる評価と同一傾向を示しており，スライバの混合 むらの定量化に画像処理技術を適用することが可能 であることがわかった.

\section{2. 混合むらの定量化}

各種の混合スライバの表面状態をモニターテレビ で確認しながら，ビデオカメラ (National 製 WVCD50）で撮影した後，ビデオ信号を画像処理装置 （PIAS 製 LA-525）へ入力し, 画像処理を行った. 本研究で使用した画像処理装置は対象物の明るさを 0 から 255 までの 256 段階の数值で表示する. その数 值を輝度と呼ぶこととする。試料から画像デー夕を 取り込む領域は 1 回の画像処理でスライバの幅方向 $200 \mathrm{~mm}$, 長さ方向 $400 \mathrm{~mm}$ である. 画素数は幅方向
200画素, 長さ方向400画素であり， 1 画素は $1 \mathrm{~mm}^{2}$ である. 絨維 1 本の太さは $19.2 \mu \mathrm{m}$ であるので, 絨 維が長さ方向に平行に整列しているならば, 1 画素 は纎維52.1本分に相当する. 画像処理により評価す る際に, 同色どうしの繊維からなる混合スライバで は明度差がないので, 輝度は同じ分布を示し, 混合 状態を識別することができない. しかし, 異色どう しの繊維からなる混合スライバの場合には明度差が 存在するので両者を識別することができる.

本研究では混合スライバの構成䋞維の様相を明ら かにするために, 最む明度の低い黒色纎維と最む明 度の高い白色緘維を選定し，これらで構成される混 合スライバを測定対象とした. 混合スライバの混合 むらを解明するには各画素の輝度から混合率を得な ければならない. 各種の混合スライバの輝度を同条 件で検出するために撮影距離, レンズの絞りなどの 撮影条件を調整した。黒色繊維の混合率が，100\%, $67 \% ， 50 \% ， 33 \% ， 0 \%$ にける5 種類の混合スライ 八゙の輝度を求めた。なお，この混合率は質量混合率 を意味する. それぞれの結果を図 1 (A), (B), (C), (D)，（E）に示す. 図中の下矢印はそれぞれの混合 スライバにおける平均輝度の位置を示す.しかし, 輝度と混合率とは比例していないことがわかる。 そ こで輝度を混合率に換算するために十分に混合した 11段階の混合スライバを用いて校正曲線を作成し た。一層正確な結果を得るために黒色緘維の混合率 が40～60\%の狭い範囲内では特に 5 段階を設定し， 精度の向上を図った。これらのスライバに対してギ ル機でダブリングとドラフティングを 5 回繰り返 し, 十分に混合を行った. 試料の明細を表 1 に示す. これらの混合スライバの輝度を求め, 混合率と輝度

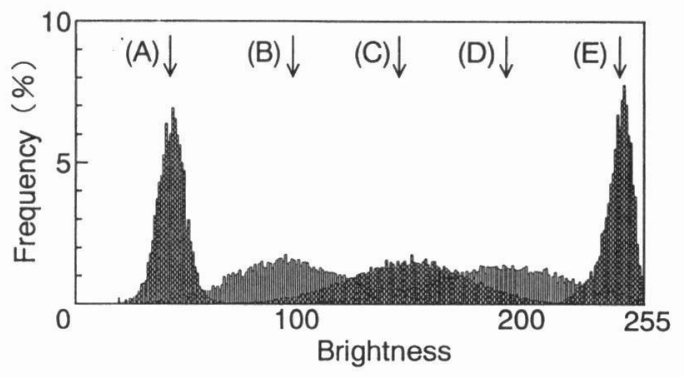

Fig. 1 Brightness distribution for various blend slivers: (A), 100/0 black and white fibers; (B), 67/33 black and white fibers; (C), 50/50 black and white fibers; (D), 33/67 black and white fibers; (E), 0/100 black and white fibers. 
Table 1 Sliver specifications for drawing up calibration curve.

\begin{tabular}{|l|c|c|c|c|c|c|c|c|c|c|c|c|}
\hline \multicolumn{2}{|c|}{} & 1 & 2 & 3 & 4 & 5 & 6 & 7 & 8 & 9 & 10 & 11 \\
\hline $\begin{array}{l}\text { Blend } \\
\text { Ratio(\%) }\end{array}$ & Black & 0 & 16 & 33 & 41 & 45 & 50 & 55 & 59 & 67 & 84 & 100 \\
\cline { 2 - 9 } & White & 100 & 84 & 67 & 59 & 55 & 50 & 45 & 41 & 33 & 16 & 0 \\
\hline Fiber & \multicolumn{10}{|c|}{ Acrylic } \\
\hline Finess & \multicolumn{10}{|c|}{76 Denier } \\
\hline Fiber Length & \multicolumn{10}{|c|}{} \\
\hline
\end{tabular}

との関係を回帰曲線で近似した，以降，各種の加工 条件で作成された混合スライバの輝度は図 2 の回帰 曲線を校正曲線として用い，混合率に換算した。こ の混合率は画像から得られた混合率を示す．画像か ら得られた混合率は検出混合率とする。 混合スライ バの混合状態は検出混合率の平均と混合むらで評価 した，混合むらの評価はこの混合率の標準偏差を用 いることとした.

ここで黒色スライバおよび白色スライバを構成し ている繊維はそれぞれ黒色，白色各単色であるにも かかわらず, 黒色繊維スライバは図 1 (A) に, 白色 織維スライバは図 1 (E) に示すように, それぞれの スライバの輝度は分布を形成している。これは繊維 自身の反射, 繊維相互の影および繊維の配列状態な ぞ表面状態の影響によるものと考えられる. 同様な 理由で混合スライバの輝度分布にも誤差分が含ま れ, 現実より拡大していると考えられる. したがっ て, 混合むらを評価する際にはこのような誤差を除 去する必要がある. 黒色纎維スライバ, 白色縬維ス ライバにおける検出混合率の標準偏差はほぼ同じ値 であったので, 混合スライバの検出混合率の標準偏

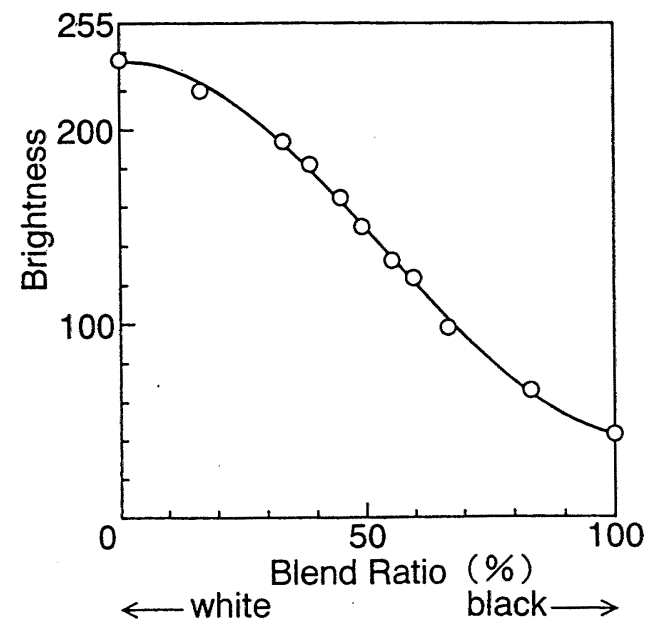

Fig. 2 Relation between blend ratio and brightness.
差を $\sigma_{\mathrm{M}}$, 黒色スライバの検出混合率の標準偏差を $\sigma_{\mathrm{B}}$, 誤差分を取り除いた混合スライバの検出混合率 の標準偏差 $\sigma_{\mathrm{G}}$ とすれば，これらの関係は次式によ って与えられる.

$$
\sigma_{\mathrm{M}}{ }^{2}=\sigma_{\mathrm{G}}{ }^{2}+\sigma_{\mathrm{B}}{ }^{2}
$$

したがって,

$$
\sigma_{\mathrm{G}}=\sqrt{\sigma_{\mathrm{M}}{ }^{2}-{\sigma_{\mathrm{B}}}^{2}}
$$

この値を用いて混合スライバの混合むらを評価し た.

\section{3. 加工条件が混合むらに及ぼす影響}

\section{1 試料スライバの作成}

混合むらを評価するための各種の試料を仏式イン ターセクティングギル機を用いて作成した．このギ ル機は上下にフォーラを有しており, フロントロー ラとミドルローラとの間のゲージ間隔は $220 \mathrm{~mm}$ で ある. ローラ間にくし状のフォーラが上側に 12 本,

下側に16本取り付けられており，1つのフォーラに 127本の針が植えられている. スライバの紡出速度 は $3.09 \mathrm{~m} /$ 分, ドラフト比は 5.95 である.

使用した混合スライバの試料明細を表 2 に示す.

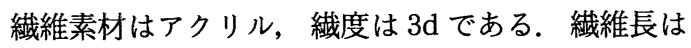
$64 \mathrm{~mm}$ と $76 \mathrm{~mm}$ の異緘維長で構成されたスライバ (以降, 繊維長 $64 / 76 \mathrm{~mm}$ と称する) と繊維長 $76 \mathrm{~mm}$ ぞうしのスライバ（以降, 緘維長 $76 / 76 \mathrm{~mm}$ と称す る）の 2 種類とした. スライバの供給方向は, Forward方向（以降，F方向とする）と Reverse 方向 (以降， $\mathrm{R}$ 方向とする) の 2 種類とした. $\mathrm{F}$ 方向とは 前工程から紡出したスライバを反転することなく, そのまま, 次工程へ供給する方式であり, $\mathrm{R}$ 方向之 は前工程から紡出したスライバを反転し，次工程へ 供給する方式である. 生産工場では $\mathrm{R}$ 方向が採用さ れている ${ }^{11)}$. 混合方式はギル工程で数本のスライバ を平行に並べ, 混ぜ合わせるスライバ混合とギル工

Table 2 Sliver specifications for evaluation of blend irregularity.

\begin{tabular}{|l|c|c|c|c|c|}
\hline \multicolumn{2}{|c|}{} & 1 & 2 & 3 & 4 \\
\hline Fiber & Black & 64 & \multicolumn{3}{|c|}{76} \\
\cline { 2 - 6 } Length(mm) & White & 76 & \multicolumn{2}{|c|}{76} \\
\hline Direction Feeding & Reverse & Forward & Forward & Reverse \\
\hline Blending Process & Sliver & Stock & Sliver & Sliver \\
\hline Blend Ratio & \multicolumn{4}{|c|}{$50 / 50$} \\
\hline Fiber & \multicolumn{4}{|c|}{ Acrylic } \\
\hline Finess & \multicolumn{4}{|c}{ 3 Denier } \\
\hline
\end{tabular}


程より前工程であるカージング工程の給毛機におい て複数の原料を混合する原料混合の 2 方式とした ${ }^{7}$. 加工条件として, ギルを通す回数, 絨維長, 供給方 向, 混合方式を選定し，これらを組み合わせて試料 を作成した。なお，これまでの報告でギルを 5 回以 上通すと混合むらはほぼ定常状態となることが報 告 ${ }^{12}$ されており，本研究においてあ，ギルを通す回 数を 5 回とした。 スライバを混合する場合には, 先 に述べたギル機を用いるが，ドラフトによりスライ バは細くなる. しかし, 測定時における試料の太さ を常に等しくする必要があるので, 同一の太さにな るようにダブリングを行った，例えば，ギルを 3 回 通すとトータルダブリング数は 216 回, ギル 5 回で 7,776回となる.

本報において測定対象とする試料は繊維長の異な る 2 種類の繊維で構成された混合スライバ, あるい は同じ繊維長どうしの繊維からなる混合スライバ で, 混合率をそれぞれ $50 \%$ とした. 繊維長が異なる 場合には織維長の短い繊維を，同繊維長の場合には いずれか一方の緘維を黒色に染色し，いずれのスラ イバも黒色繊維と白色繊維からなる混合スライバと した.

\section{2 測定結果}

ギルを通す回数，スライバを構成している成分繊 維の繊維長, 供給方法および混合方式がスライバの 混合状態に及ぼす影響を考察した。

\section{(1) 工程の影響}

ギルを通す回数，すなわちダブリング数が混合ス ライバの混合状態に及ぼす影響を検討した，緎維長 76/76mm で R 方向にスライバ混合を行い，ギルを 5 回通した。 ギルを通したそれぞれの回数における スライバの表面写真を図 3 に示す．紙面の左右方向 がスライバの長さ方向, 上下方向が幅方向を示す. ギルを 1 回通した場合では, 黒色織維, 白色織維は 全く分離している，ギルを 2 回通すと黒色織維, 白 色織維は部分的に集合しており，まだブロック状の ままであり，あまり混合していない，ダブリング数 の増加に伴い, 次第に混合が進み, ブロックが小さ くなる, あるいは黒色繊維, 白色繊維が次第に筋状 を呈するようになる，さらにギルを通す回数が増大 し, ギルを 4 回および 5 回通した結果, ブロック， 筋はそれほど目立たなくなり，黒色緎維および白色 纎維が全面に散在している。 そしてスライバの表面 は灰色となり, 混合がよく進行したことを示す。

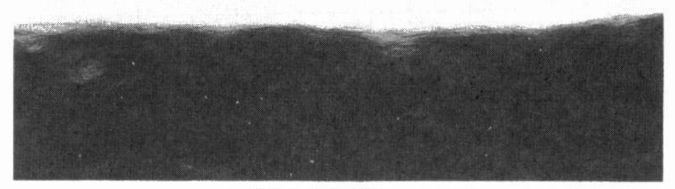

(1)1st Gilling

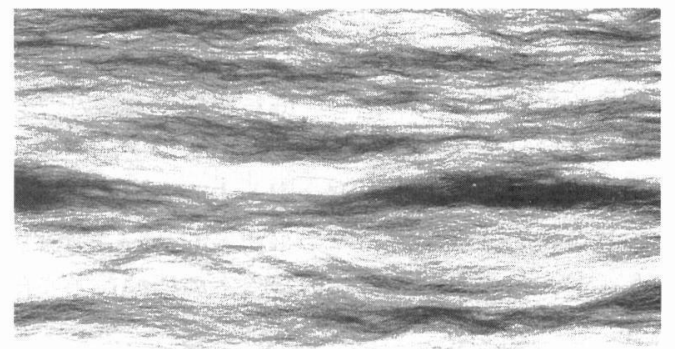

(2)2nd Gilling

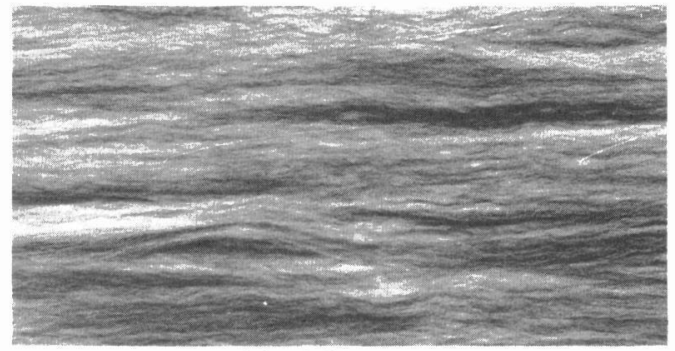

(3)3rd Gilling

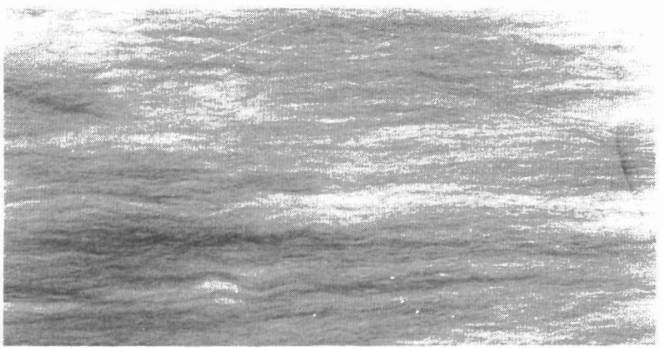

(4)4th Gilling

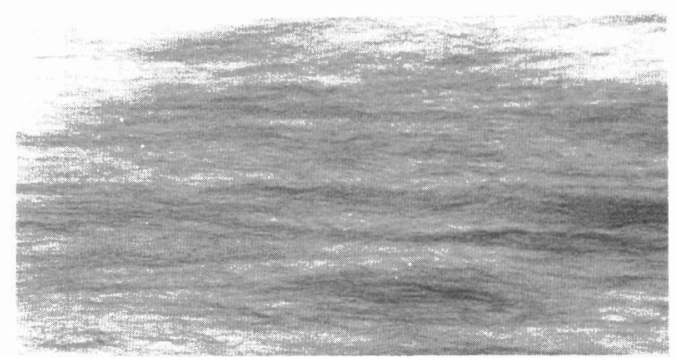

(5)5th Gilling

Fig. 3 Typical photographs for each stage of gill sliver in sliver blending process. 
図 4 はそれぞれのスライバをギルに通す回数の増 加，すなわちダブリング数が増加した場合における 黒色纎維の検出混合率のヒストグラムを示す。ギル を 1 回通した場合には $0 \%$ と $100 \%$ の両端に大きな ピークを有しており, 前述の写真における黒色繊維 と白色繊維が分離し, 全く混合されていないことと 対応している. ギルを 2 回通しても，まだ黒色繊維 と白色纎維に分離しているが, 部分的には混合して いる. 以降，ギルを通す回数が増加すると次第に分
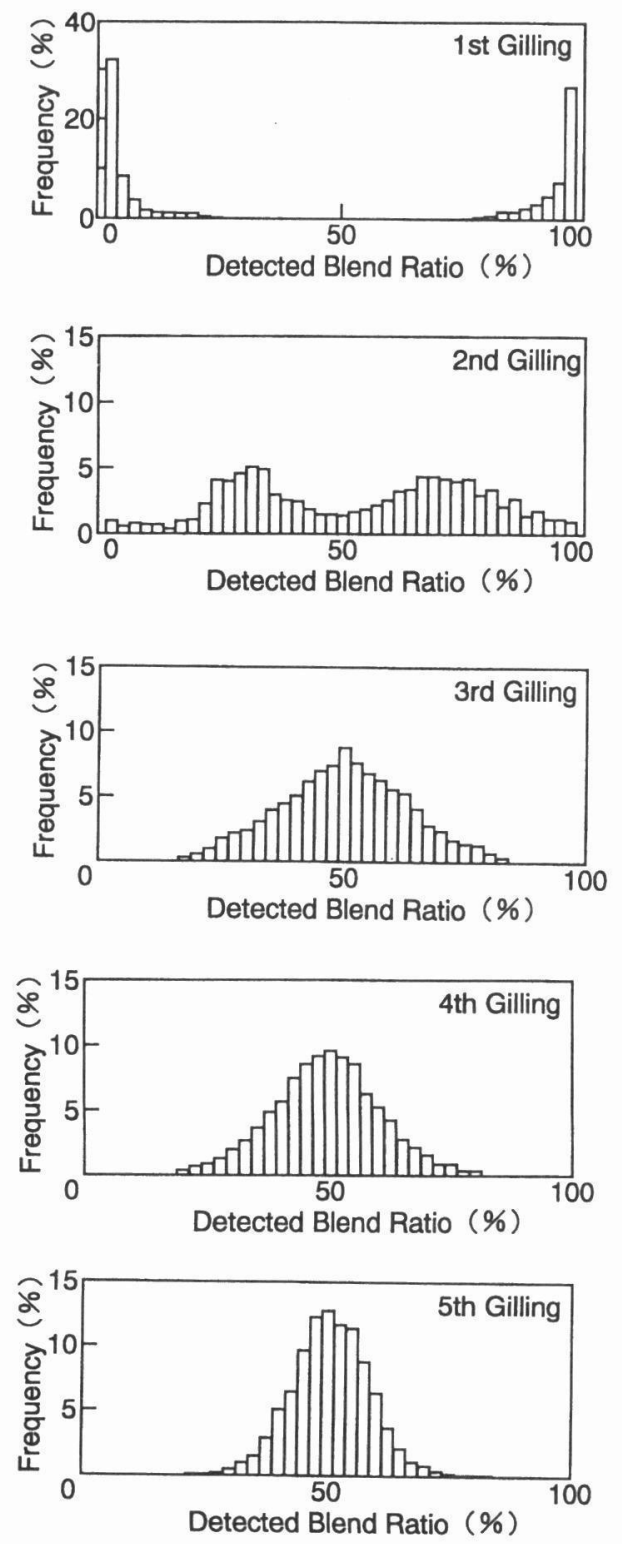

Fig. 4 Blend ratio distribution for each stage of gill sliver in sliver blending process.

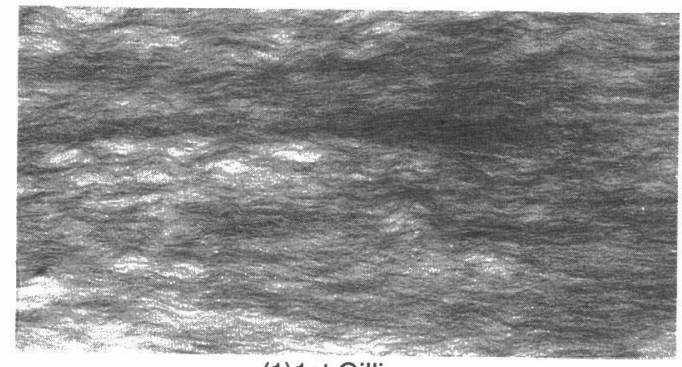

(1)1st Gilling

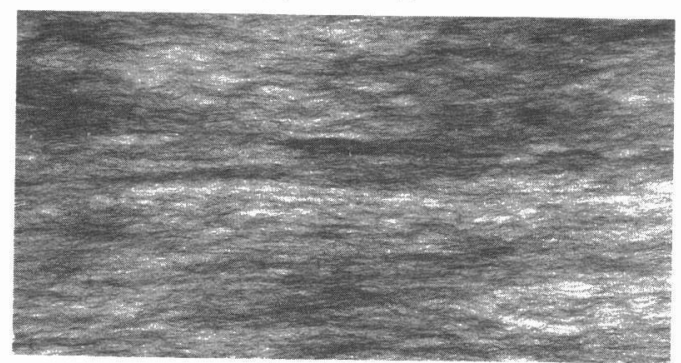

(2)2nd Gilling

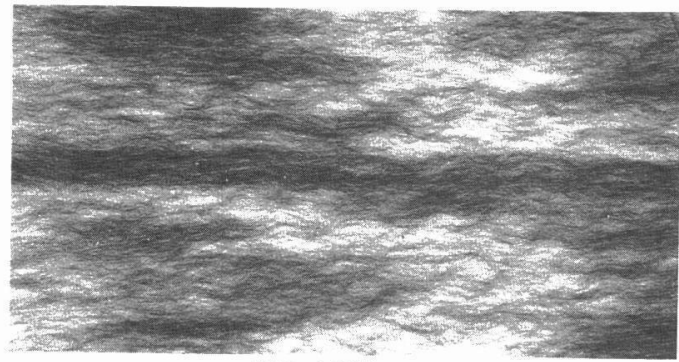

(3)3rd Gilling

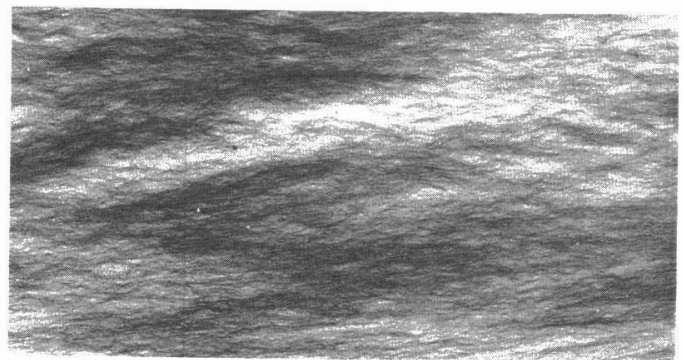

(4)4th Gilling

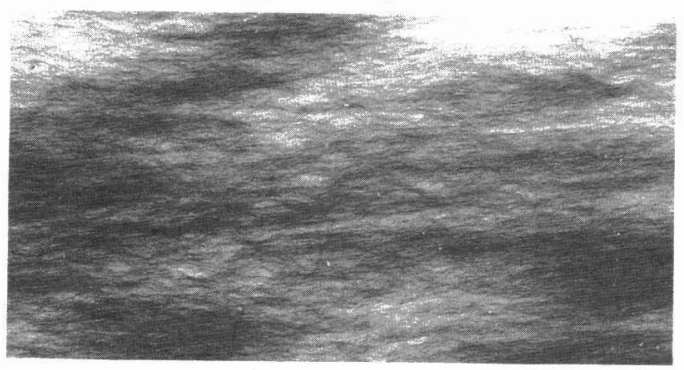

(5)5th Gilling

Fig. 5 Typical photographs for each stage of gill sliver in stock blending process. 
布の範囲が狭くなり，50\%付近のピーク值が大きく なっていく．ギルを 5 回通したところ，50\%付近を 中心に分布幅が狭く, 混合が進んでいることを示し ている.

原料混合スライバの各ギル回数における表面の様 相を図 5 に示す.繊維長は $76 / 76 \mathrm{~mm}$, 供給方向は R 方向である. 原料混合ではギルを通す回数によら ず，ほぼ同様な様相を示している。

図 6 は原料混合スライバをギルを通す回数の増
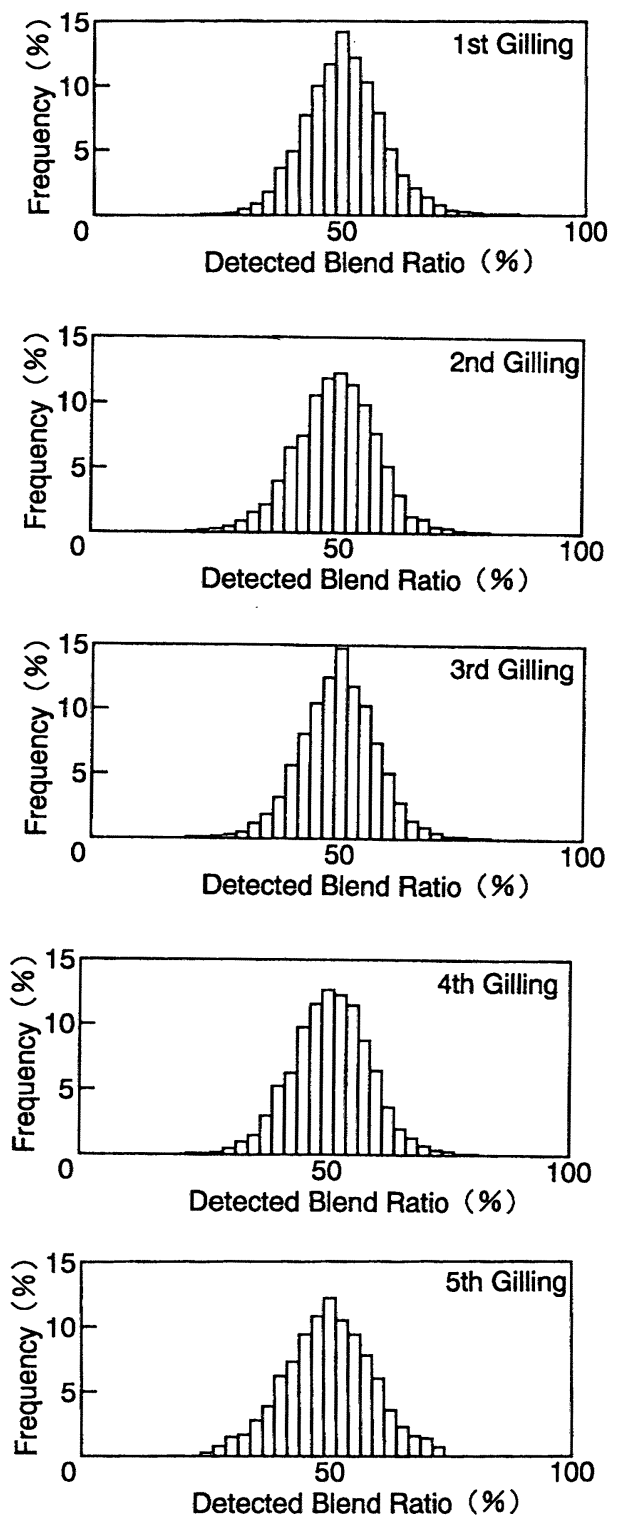

Fig. 6 Blend ratio distribution for each stage of gill sliver in stock blending process.
加，すなわちダブリング数が増加した場合における 黒色繊維の検出混合率のヒストグラムを示す。ギル を通す回数にかかわらず，いずれの場合においてす 50\%付近にピークをあち，狭い分布幅となってお り, 図4のスライバ混合におけるヒストグラムの変 化とは全く異なっていることがわかる.

各種の加工条件で作成した混合スライバにおける 黒色繊維の平均検出混合率に及ぼすギルを通す回数 の影響を図 7 に示す．スライバ混合および原料混合 いずれの場合むギルを通す回数によらず，この平均 混合率は $50 \%$ 付近に分布しており，画像処理により 検出された混合率は質量混合率と同様に $50 \%$ 付近に 分布している. このことより, 画像処理で混合率を 評価してあ十分信頼できることがわかった.

図 8 は検出混合率の標準偏差に及ぼすギルを通す 回数の増加, ダブリング数が増加した場合の影響を 示す．スライバ混合において，ギルを通した回数が 少ない段階では標準偏差は大きな値であり, 黒色繊 維と白色絾維はほとんど混合していないことを示し ている. 以降, ギルを通す回数の増加に伴い, 標準 偏差が小さくなり, 混合が進んでいくことを示して いる. ギルを 4 回あるいは 5 回通すと標準偏差は一 定值に収束する傾向が見られ, 混合むらが減少した と思われる. 一方, 原料混合スライバにおける標準 偏差の值はスライバ混合と比較すると小さく，しか もギルを通す回数によらず，ほぼ一定の值を示し た.このことはギル機に供給する段階ですでに十分 に混合が進み, 混合むらが少ないことを示してい る.

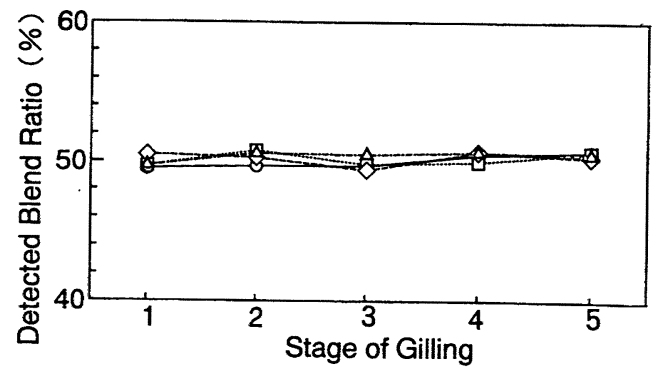

Fig. 7 Influence of gilling on detected blend ratio: $\diamond$, fiber length $(76 / 76 \mathrm{~mm})$, forward direction feeding and sliver blending process; $\triangle$, fiber length $(64 / 76 \mathrm{~mm})$, reverse direction feeding and sliver blending process; $\diamond$, fiber length $(76 / 76 \mathrm{~mm})$, reverse direction feeding and sliver blending process; $\bigcirc$, fiber length $(76 / 76 \mathrm{~mm})$, forward direction feeding and stock blending process. 


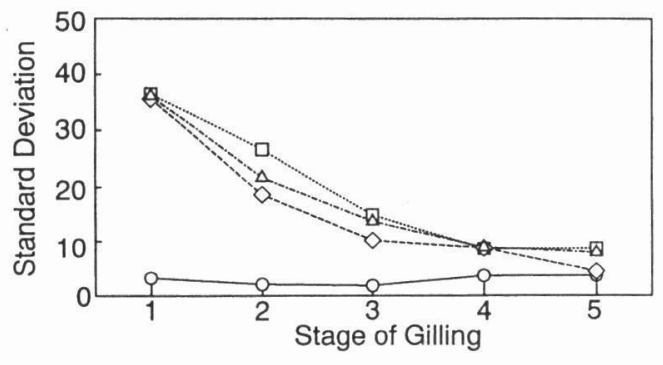

Fig. 8 Influence of gilling on standard deviation of detected blend ratio :

$\diamond$, fiber length $(76 / 76 \mathrm{~mm})$, forward direction feeding and sliver blending process ; $\triangle$, fiber length $(64 / 76 \mathrm{~mm})$, reverse direction feeding and sliver blending process ; $\diamond$, fiber length $(76 / 76 \mathrm{~mm})$, reverse direction feeding and sliver blending process ; $\bigcirc$, fiber length $(76 / 76 \mathrm{~mm})$, forward direction feeding and stock blending process.

\section{（2）構成繊維長の影響}

繊維長76/76mm, 64/76mm の繊維長の異なる混 合スライバを $\mathrm{F}$ 方向にギルを 3 回行った場合の混 合状態について考察する. 両者の平均検出混合率之 標準偏差の結果を図 9 に示す.この平均混合率は両 者とあほぼ $50 \%$ と同様な值である。標準偏差におい

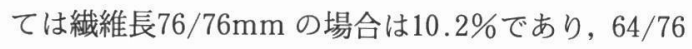
$\mathrm{mm}$ の $13.8 \%$ よりさい結果を得た. スライバがド ラフトされる場合, フロントローラにもバックロー ラにあ把持されない浮遊瀻維の挙動がドラフトむら を左右するといわれている ${ }^{13)}$. ゲージ間隔が同じな らば, スライバを構成している繊維の繊維長が短い ほどこの浮遊繊維が多く, 混合むらを生じると考え られる.したがって, 緘維長が長いスライバの場合 には混合むらが少なく, 繊維長 $76 / 76 \mathrm{~mm}$ が64/76

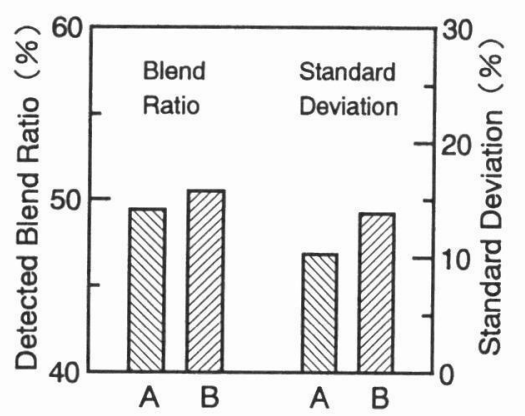

Fig. 9 Comparison of detected blend ratio (left) and standard deviation between fiber length difference : (A), fiber length $(76 / 76$ $\mathrm{mm})$; (B), fiber length $(76 / 64 \mathrm{~mm})$. $\mathrm{mm}$ より混合が良好であると考えられる.

\section{（3）供給方向の影響}

絨維長 $76 / 76 \mathrm{~mm}$ の混合スライバをギル 3 回, 供 給方向が $\mathrm{F}$ 方向， $\mathrm{R}$ 方向における混合状態を検討す る. 図10に平均検出混合率と標準偏差の結果を示 す. 両者と屯この平均混合率は $50 \%$ 前後とほぼ同じ 値である. 一方, 標準偏差は $\mathrm{F}$ 方向の場合, $15.0 \%$ である.しかし， R 方向は $10.2 \%$ と 方向より小さ な值である.すなわち，ギルを通した回数が同じ場 合には R 方向の混合むらが少なく, 混合が良好であ ることがわかる，スライバを構成している䋐維には 先端, 後端フックを有する繊維が存在しており,こ のフック繊維の存在が混合状態に影響を与えるもの と思われる. ドラフトした場合には, フックは先端 より後端が減少しやすい，F 方向では供給方向が同 じであるので, 先端フックは減少しないが, 後端フ ックは減少する。しかし， R 方向では先端フックは 反転し, 後端フックとなり, ドラフトにより減少す る ${ }^{14)}$. これが工程を通すごとにスライバを反転する 理由の 1 つである. また, Foster ${ }^{15)}$ はコーマ工程以 降のスライバの綫維配列について述べており, 繊維 先端がそろった方向にドラフトするとむらが顕在化 し, 反対方向にドラフトするとむらは顕在化しない

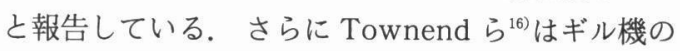
実験で明らかにしたようにスライバを F 方向に供 給し, ドラフトした場合には, 繊維集団が分離され ることは困難であるが, $\mathrm{R}$ 万向に供給した場合には 繊維長分布を有するスライバの場合, 繊維集団は分 解し, 破壊すると報告している.

このようにスライバの供給方向の反転により， フ ック織維の減少によるむらの均亦化, および織維集 団の分解による繊維の平行化, 直線化が進み, 混合

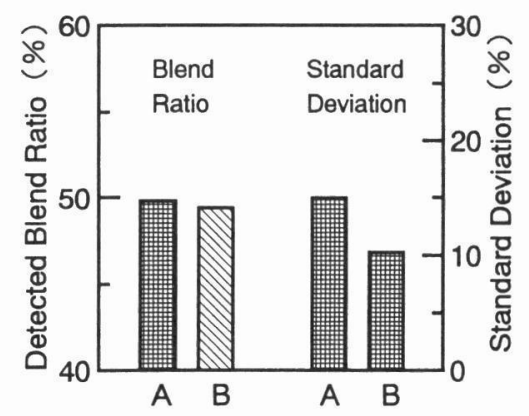

Fig. 10 Comparison of detected blend radio (left) and standard deviation between forward and reverse direction feeding (A), forward direction feeding ; $(\mathrm{B})$, reverse direction feeding. 
が進むと考えられる。

\section{（4）混合方式の影響}

図11にギルを 3 回通した原料混合とスライバ混合 における平均検出混合率と標準偏差の結果を示す. この平均混合率においては両者とあほぼ50\%前後と ほぼ同じ值である. 標準偏差では原料混合の場合 $1.9 \%$ とライバ混合の $10.2 \%$ と比較して非常に小 さな值である．原料混合された混合スライバは混合 むらが少なく，よく混ざっていたあのと思われる.

このように汎用画像好理装置により求めた結果は 視覚による評価結果と同様な傾向を示している. し たがって, 画像処理技術を混合スライバの混合むら の測定, 定量化に適用することは有効であることが 明らかとなった。

\section{4.結 言}

本報では, 混合スライバを CCD カメラで撮影後, 画像処理装置により，スライバの表面の様相を解析 し，定量化することを目的とした。ささらにギルを通 す回数, 繊維長, 供給方向および混合方式の加工条 件がスライバの混合むらに及ぼす影響を検討した.

得られた結果をまとめると，次のようになる.

(1) 輝度と黒色繊維の質量混合率の関係を示す回

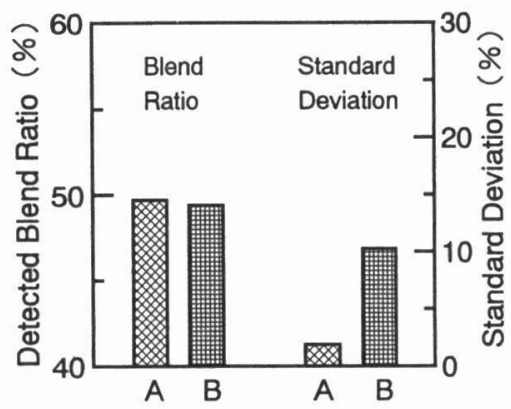

Fig. 11 Comparison of detected blend ratio (left) and standard deviation between stock and sliver blending process :
(A), stock blending process ;
(B), silver blending process.

帰曲線を用いて, 混合スライバの輝度から黒繊維 の混合率を求めることができる.

（2）混合スライバの混合状態は画像から得られた 平均混合率と混合むらにより定量的に評価するこ とができる.

（3） スライバ混合の場合，ギルを通す回数の増加, すなわち，ダブリング数が増加した場合には画像 から得られた混合率の標準偏差は著しく低下す る. 混合むらが少なくなり，混合が進行する。一 方, 原料混合では, ギルを通す回数にかかわらず, 混合むらは少なく，ギルを通す回数が増加しても 混合はほとんど進んでおらず，最初から良好な混 合状態を示している.

(4) スライバ混合において, 同繊維長どうしの混合 は, 異繊維長よ゙うしの場合より混合むらが少な く，良好な混合を示す.

（5）供給方向の影響については $\mathrm{R}$ 方向が $\mathrm{F}$ 方向よ り良好な混合を示す。

\section{参考文献}

1）立石，奥秋；織工試彙報，p. 81，第18号（1951）

2) “ドラフトの理論と実際”, p. 391, 日本䋐維機械学会 (昭和 33年）

3）“ドラフトの理論と実際”, p. 393, 日本紻維機械学会 (昭和 33年)

4) Lund.; J. Text. Inst., 43, 375 (1952)

5) Coplan, Klein; Text. Res. J., 25, 743 (1955)

6）近田, 岡村, 黒崎, 渡辺, 岡崎 ; 紻機誌, 45, T172 (1992)

7) 近田, 岡村, 黒崎, 渡辺, 安田 ; 織機誌, 46, T61 (1993)

8）近田，岡村, 黒崎, 野田 ; 織機誌, 46, T179 (1993)

9）岡村, 近田, 黒崎, 土井 ; 緎機誌, 49, T159 (1996)

10）岡村, 近田, 野田, 田家, 吉倉 ; 織機誌, 49, T231 (1996)

11）近田, 黒崎, 岡村, 横井, 渡辺 ; 織機誌, 44, T11 (1991)

12) “ドラフトの理論と実際”, p. 397, 日本緎維機械学会 (昭和 33年)

13）“基礎瀻維工学 I”, p. 238, 日本緎維機械学会（昭和46年）

14）“基礎織維工学 I”, p. 251 , 日本緎維機械学会（昭和46年）

15) G. A. R. Foster; "The Principles of Roller Drafting and The Irregularity of Drafted Materials", The Textile Institute, P.89 (1958)

16) P. P. Townend, T. F. Griffin; J. Text. Inst., 46, T1.53 (1955) 